\title{
The Impact of Iran-Iraq War in the Middle East
}

\author{
Dr. Najleh Khandagh*
}

Associated Professor, Tarbiat Modaress University

DOI: $10.36347 /$ sjahss.2020.v08i07.002

| Received: 19.06.2020 | Accepted: 03.07.2020 | Published: 08.07.2020

*Corresponding author: Dr. Najleh Khandagh

Abstract

A border dispute between Iran and Iraq, which developed into a major war and the conflict effectively transformed the entire Middle East, too. From 1980 to 1988, Iran and Iraq fought the longest conventional war of the twentieth century. The tragedies included the slaughter of child soldiers, the use of chemical weapons, the striking of civilian shipping in the Gulf, and the destruction of cities. The Iran-Iraq War offers an unflinching look at a conflict seared into the region's collective memory but little understood in the West. The protracted war between these neighboring Middle Eastern countries resulted in at least half a million casualties and several billion dollars' worth of damages, but no real gains by other side. Started by Iraq dictator Saddam Hussein in September 1980, Iraq was forced on the strategic defensive, Iran was unable to reconstitute effective armored formations for its air force and could not penetrate Iraq's borders deeply enough to achieve decisive results. The end came in July 1988 with the acceptance UN Resolution 598. In 1988 Saddam Hussein surrendered that gain when in need of Iran's neutrality in anticipation of the 1991 Gulf.

Keywords: Iran, Iraq, Invasion, War, Military.

Copyright @ 2020: This is an open-access article distributed under the terms of the Creative Commons Attribution license which permits unrestricted use, distribution, and reproduction in any medium for non-commercial use (NonCommercial, or CC-BY-NC) provided the original author and source are credited.

\section{INTRODUCTION}

The Iran-Iraq War permanently altered the course of Iraqi history. It strained Iraqi political and social life, and led to severe economic dislocations. Viewed from a historical perspective, the outbreak of hostilities in 1980 was, in part, just another phase of the ancient Persian-Arab conflict that had been fueled by twentieth-century border disputes. Many observers, however, believe that Saddam Hussein's decision to invade Iran was a personal miscalculation based on ambition and a sense of vulnerability [1]. Saddam Hussein, despite having made significant strides in forging an Iraqi nation-state, feared that Iran's new revolutionary leadership would threaten Iraq's delicate Sunni Shia balance and would exploit Iraq's geostrategic vulnerabilities-Iraq's minimal access to the Persian Gulf.

The Iran-Iraq War was multifaceted and included religious schisms, border disputes, and political differences. Conflicts contributing to the outbreak of hostilities ranged from centuries-old Sunniversus-Shia and Arab-versus-Persian religious and ethnic disputes, to a personal animosity between Saddam Hussein and Ayatollah Khomeini. Above all, Iraq launched the war in an effort to consolidate its rising power in the Arab world and to replace Iran as the dominant Persian Gulf state. Phebe Marr, a noted analyst of Iraqi affairs, stated that "the war was more immediately the result of poor political judgement and miscalculation on the part of Saddam Hussein, and "the decision to invade, taken at a moment of Iranian weakness, was Saddam's" [2].

Three things distinguish the Iran-Iraq War. First, it was inordinately protracted, lasting longer than either world war, essentially because Iran did not want to end it, while Iraq could not. Second, it was sharply asymmetrical in the means employed by each side, because though both sides exported oil and purchased military imports throughout, Iraq was further subsidized and supported by Kuwait and Saudi Arabia, allowing it to acquire advanced weapons and expertise on a much larger scale than Iran. Third, it included three modes of warfare absent in all previous wars since 1945: indiscriminate ballistic-missile attacks on cities by both sides, but mostly by Iraq; the extensive use of chemical weapons (mostly by Iraq) [3]; and some 520 attacks on third-country oil tankers in the Persian Gulf-for which Iraq employed mostly manned aircraft with anti shipping missiles against tankers lifting oil from Iran's terminals.

Border clashes took place sporadically early in 1980 and, with Iran's armed forces weakened by purges, 
Saddam hoped to replace the deposed shah as regional strongman. He was alarmed, too, by the radicalising effect of the Islamic revolution on Iraq's restive Shia majority and wanted to improve access to the Gulf through the Shatt al-Arab. Over time he enjoyed the discreet support of the west, with the US providing satellite intelligence on Iranian deployments and European countries supplying armaments and raw materials for gas and chemical weapons. Iran's continuing suspicions of America and Europe cannot be understood without remembering that grim period. Washington wanted both countries to bleed, but it feared Iran more.

One would be hard pressed to find a region in the world today where conflict is as prevalent as the Middle East. Seemingly every day, Americans are greeted with news reports of rocket attacks, terrorist threats, and instability in this part of the world. Yet, this is nothing new; Arab states have been warring with each other for centuries. One of the most volatile, bloody, and recent of these conflicts was the Iran-Iraq War of the 1980s. This war set the stage for many of the current problems in the Middle East, when Saddam Hussein launched what he hoped would be an easy victory over a disorganised enemy. By its end, nearly eight years later, more than one million people were dead and both countries deeply scarred. It has marked the politics of the Middle East ever since.

Saudi Arabia and other neighboring Arab countries also felt threatened by the 1979 Islamic Revolution for its Shia affiliation. As a result, Saddam was then planned as a champion of Sunni Muslims in the face of the new ayatollah Khomeini's -led revolution. Iraqi Shias then became the first victim of this new found sectarianism, as demonstrated by the outcome of the 1991 Iraqi uprisings in the south.

Many Iraqi youth participated in the conflict, and those who were lucky to be unscathed on the war front continued to suffer from post-traumatic stress. The war also created a generation of widows and orphans in which Iraqi society as a whole was neither able to recover from nor the state able to reintegrate due to the 1991 Gulf War and the subsequent punitive sanctions.

War is one of the critical determinants of health status of populations in many parts of the world. Armed conflict has been a major cause of deaths and morbidity.

\section{RESULT AND DISCUSSION}

With a history dating back to ancient and Biblical times, the Middle East has a long tradition of conflict. The seeds for the Iran-Iraq War were laid years before the first shots were fired. Iran saw major regime changes prior to the war. For several decades, Iran had a pro-Western government. Radical factions within Iran were angered by this, and in 1979, the Iranian
Revolution overthrew the government and began the new Islamic Republic [4].

Iraq had a similar story before the war. In the late 1960s, a coup or a seizure of power [5], occurred when the Ba'ath Party took control. The Ba'ath Party was a regional branch of a larger political movement sweeping the Middle East that was socialist in nature and had a strong nationalist appeal. By July 1979, General Saddam Hussein, a leading Ba'athist figure, was the Iraqi president. Thus, in 1979, both Iraq and Iran saw major leadership changes that ultimately opened the door for years of conflict to come between the two countries [6].

Tensions between the two countries built rapidly following the Iranian Revolution when the country's new leader, Ayatollah Ruhollah Khomeini, declared that Iraq needed to stage another coup and overthrow the ruling Ba'ath party. This threatened Hussein and the Ba'athists, who saw the new Iranian government as a threat to Iraq. Numerous border disputes intensified these disagreements.

Saddam Hussein had large aspirations as Iraq's leader. He wanted to expand his country's power, prestige, and influence, hoping to become the leading nation in the Middle East. One way of accomplishing many of his goals was to attack Iran, gaining new oil fields, more land and power, and dealing a blow to the threatening regime.

After the Revolution 1979 in Iran, the whole region was threatened by the Islamic nationalist revolutionaries. Thus, Saddam to alleviate the threat of the revolution formed the paramilitary force, an ideological taskforce within the Baath Party called the Fedayeen Saddam to deal with the growing Shiite influence in Iraq, especially in south. The Fedayeen were irregular force units that operates under direct command of the Presidential Palace.

Iran's complex, violent military history encompasses two world wars, foreign intervention, antigovernment revolts, border disputes, a revolution, a war against Iraq that lasted over eight years, and its desperate quest to become a nuclear power, but Iran's current bellicosity on the world stage was shaped by centuries of military defeat and humiliation foreign influences from the likes of Russia and Great Britain.

War begins by late September 1980, Iraq began a massive invasion of Iran along the country's southwestern border with Iraq. Because of the mountainous terrain, much of the early attacking was done by air strikes on Iranian air fields. When ground forces went into Iran, they encountered various military and police groups that were all fighting without any overall coordination. Soon, Iran began launching air assaults against Iraq, specifically targeting Baghdad. 
The Iran-Iraq War is one of the largest, yet least documented conflicts in the history of the Middle East. Drawing from an extensive cache of captured Iraqi government records, the impact on oil production so essential to both countries Pierre Razoux also looks at the international picture. From the United States and Soviet Union to Israel, Europe, China, and the Arab powers, many nations meddled in this conflict, supporting one side or the other and sometimes switching allegiances [7].

America had no natural partners in the IranIraq War, but its interests dictated that the United States allow neither Saddam nor Khomeini to dominate the region and the world's energy supply. For most of the war, it was Iran that appeared on the verge of victory, so Washington had little choice but to support Iraq. When the war began, Iran held dozens of American diplomats hostage and even tortured some. Only after 444 days in captivity did Iran let the American hostages go [8]. In contrast to Khomeini, many Americans hoped that the Iraqi leader was somehow redeemable and could be worked with as a difficult but manageable partner.

In the months leading up to the outbreak of war, Saddam began strengthening and mobilizing his massive military forces. Iraq had nearly 200,000 soldiers, with thousands of tanks and hundreds of aircraft [9] Conversely, the Iranian army had just undergone severe officer purges and executions. But Iran still had a strong air force, meaning that any war against them would not be easy. When Iraq launched attacks on Iran and the fighting began in earnest.

In 1980 President Saddam Hussein of Iraq abrogated the 1975 agreement granting Iran some 518 sq $\mathrm{km}$ (200 sq miles) of border area to the north of the Shatt-al-Arab waterway in return for assurances by Iran to cease military assistance to the Kurdish minority in Iraq, which was fighting for independence. Calling for a revision of the agreement to the demarcation of the border along Shatt-al-Arab, a return to Arab ownership of the three islands in the Strait of Hormuz (seized by Iran in 1971) [10], and for the granting of autonomy to minorities inside Iran, the Iraqi army engaged in a border skirmish in a disputed but relatively unimportant area, and followed this by an armored assault into Iran's vital oil-producing region. The Iraqi offensive met strong Iranian resistance, and Iran recaptured territory from the Iraqis.

On 22nd September 1980, the Iraqi army crossed the internationally recognized Iran-Iraq border. This conflict later known as the First Persian Gulf War, which lasted up to 20th August 1988, when the pre1980 status quo was restored. This long eight-year war consumed almost all man, machine and resources of the both sides, and probably responsible for the Invasion of Kuwait, the First Gulf War in August 1990. Although, this war and the conflicts before all started over dominance of the Persian Gulf region and the Arvand Rud/Shatt al-Arab Waterway, also the sovereignty over the oil rich Khuzestan province.

1980 Sept. 7-Iraqi President Saddam Hussein claims full sovereignty over the Shatt al Arab waterway. Sept. 19-Iran shells Iraqi side of Shatt al Arab. Sept. 20-23-Iraqi warplanes strike airport in Tehran; army advances to Karun River, several hundred miles into Iran. Iraq launched a full-scale invasion of Iran on 22 September 1980 [11]. The Iraqi Air Force launched surprise air strikes on ten Iranian airfields with the objective of destroying the Iranian Air Force. The attack failed to damage the Iranian Air Force significantly; it damaged some of Iran's airbase infrastructure, but failed to destroy a significant number of aircraft. The Iraqi Air Force was only able to strike in depth with a few MiG-23BN, Tu-22, and Su-20 aircraft, and Iran had built hardened aircraft shelters where most of its combat aircraft were stored. Sept. 28-U.N. Security Council adopts Resolution 479 calling for a cease-fire. Iran rejects the call [12].

Also, the Iraqi intelligence was well informed that the Iranian forces in Khuzestan consisted of only several ill equipped and under-strength Battalions with handful operational company-sized tank units in Ahvaz and Dezful. The same situation was circulating around the Iranian Air Force in Khuzestan, several commanders and pilots were executed during the random revolutionary executions, purged or imprisoned. Also, the Air Force experiencing lack of technicians and spare parts. In such circumstances, the Iraqi leader decided to carry out a surprise airstrike against the Iranian military bases and the country's infrastructure prior to the main invasion. 27 On 22nd September 1980, at 12:00 pm six Iraqi Army Divisions crossed the border and opened a full scale invasion along a front measuring $644 \mathrm{Km}$. But, four of those army divisions were only focused on the Khuzestan province to cut off the Arvand Rud/Shatt al-Arab Waterway from the rest of Iran, and to establish a territorial security zone on the eastern shore of the waterway. On the Southern Front, two Iraqi Army Divisions included the Iraq's 5th-Army and the Iraq's 9th-Army sieged the strategically important towns of Abadan and KhoramShahr. The Iraqi troops eventually captured the city of KhoramShahr, but failed to seize the important oil-refining center of Abadan [13]. Moreover, on the Central Front (Dezful's Front) the Iraq's 10th-Army was moving toward Susa and the Iraq's 11th- Army of the Red Hat Special Forces of the Baathists was advancing toward Dezful.

Saddam began by attacking the oil-producing province of Khuzestan and captured Khorramshahr a month after fighting began. But it was, one historian has written, "a catastrophic miscalculation" [14]. Nor did he secure the mantle of Arab leadership he aspired to, even 
though the Saudis and the Gulf states bankrolled the war effort. Iran, with a population of 50 million to Iraq's 17 million, mobilized to defend the revolution. By the summer of 1982 Iraq was on the defensive and remained. The death toll, overall, was an estimated 1 million for Iran and 250,000-500,000 for Iraq.

By November, Iraqis advanced towards Dezful and Ahvaz, but failed in occupying those two settlements. Abadan, KhoramShahr, Ahvaz and Dezful were the main targets in Khuzestan for Saddam, but that dream soon gone. By December 1980, the Iraqi offensive had bogged down about 50-75 miles (80-120 $\mathrm{Km}$ ) inside Iran after meeting unexpectedly strong Iranian resistance.

The Invasion of Khuzestan, also known as the Battle of Nassiriyeh was the major action during the Iran-Iraq War, when the Iraqi Army units and elements of the 3rd Armored Divisions and 31st, 33rd, 66th Special Force Brigades, along with 49th, 2nd, 429th, 23rd Infantry Brigades, also 3rd Republican Guards Special Forces Battalions cross the Arvand Rud/Shatt al-Arab Waterway near the Iraqi town of Kharkiya alongside of the Basra-Baghdad highway and then head south to capture the cities of KhoramShahr and Abadan Island.

On 22nd September 1980 in the afternoon, Saddam launched the invasion toward KhoramShahr and Abadan, which followed by air strikes and heavy shelling through Iraqi town of Tannumah under command of Colonel Ahmad Zeidan. Over the same night, the Iraqi tanks moved in towards the KhoramShahr-Ahvaz highway, also the mechanized divisions began to secure the suburbs of the city. This process roughly took three to four days. On 23rd September of the early morning, the Iraqi troops partially surround the city. By 29th September at night, the Iraqis managed to cutoff the city from the neighboring town of Abadan as well as the Khuzestan province. On 30th September at early morning, the Iraqis entered the city via the southernmost port.

The psychological aspects of the fall of KhoramShahr, encourage the Iranian leaders to launched Operation Scorch Sword, it was the show of the Iranian Air Force strength that severely damaged the Osirak Nuclear Reactor near Baghdad. By 1st October, Baghdad had been subjected to eight air attacks. In response, Iraq launched aerial strikes and shelling against the Iranian targets mostly in urban areas such as Abadan, Ahvaz and Dezful. By 11th October, the outskirts of the city was effectively under Iraqi control [15]. From 21st to 24th October, the Iraqis managed to capture the KhoramShahr's bridge, which linked the city to Abadan and rest of the governmental facilities. On 25th and 26th October, the Iranian Air Force initiated airstrikes over the nights as cover for the remaining defenders to evacuate the city towards the
Karun River. However, on 10th November 1980 at early morning, the city was in full control of the Iraqis [16].

On 22nd September 1980, the Iraqis crossed the Karun River and reached the city limits of Abadan, but retreated back tactically to examine the strength of the Iranian forces. By 3rd November 1980, the Iraqi forces in the region received reinforcement of the Armored Division included of two-hundred tanks and then surround Abadan from the northeast. Also, to crackdown the Iranian Army resistance another additional Iraqi forces made of two Armored Divisions crossed the Karun River and bypassed the under siege city of KhoramShahr and stationed north of Abadan. From November to June 1980, the Iraqi Army managed to surround Abadan from land and occupy a portion of the city. But, failed to safeguard the Karun's riverbank, which allowed the Iranians to send reinforcement and supplies at cover of night by boat and helicopter inside of the Abadan Island. Despite stiff resistance, the Iraqis kept up a siege for several months. But, never succeeded to capture the city or the oil refinery. During the siege, large sections of the Abadan's urban areas and the refinery were badly damaged or destroyed by bombing. In January 1981, only five months after the Battle of Dezful; the Iraqi forces attacked the Abadan Island, but failed to secure the island. On 22nd September 1981, Iranian forces launched their first major human-wave counteroffensive called Operation Samen al-Aemeh, which last up to 24th September. During this battle, the siege of Abadan was broken, and eventually in 1982 resulted the driving out of Iraqi troops from KhoramShahr [17].

During the war, Saddam's military strategy was forced to yield into three tactics and periods. At the onset of the conflict he was pushing a decisive limited operation to either occupy historic conflict areas or initiate peace negotiation on the waterway. The second stage of the war was developed on the static defense and adaptation of the Iraqi armed forces against the Iranian human-wave offensive strategy. The third stage of the war was centered on the Clausewitz, the psychological aspect of the war through utilization of the strategic bombing, especially on the urban areas.

1981 May-Oct.-Iran counterattacks, eventually pushing Iraqis back across the Karun River. Saddam was hoping to progress the Operation al-Nassiriyeh in short time with limited resources to occupy Khuzestan or pursue a quick negotiated peace on the waterway, but the size and number of the rivers in Khuzestan, and also location of the Zagros Mountains dominating from north and east over the operation area, forced the Iraqis to stop cross the Karkheh, Karun and Dez Rivers. This geographical issues undermined the whole invasion. The Iraq's limited progress of this operation was quickly repelled; as the Iranian regained virtually all lost territory during counteroffensive of the Operation 
Fath al-Mobeen on 21st March 1982 in Dezful region and the Operation Beit al-Moqadas on 30th April 1982 in Abadan and KhoramShahr regions. From 1982 up to 1988, Iran was on the offensive in the Iraqi territory until near the end of the war, which Saddam received financial and military aid from the Gulf Cooperation Council (GCC) and other superpowers. The new scenario forced the international isolated regime of Iran to initiate the peace talks [18].

The Battles of Central Front: during the early stage of the war, the Iranian Army attempted two main offensives to protect the major populated area of Dezful at north of Khuzestan as well as Ahvaz, through utilizing the geographical barriers of the Karkheh, Karun and Dez Rivers. The Operation Dezful: by late September 1980, the Iraqi Army succeeded to camp along the western banks of Karkheh and Karun Rivers. Thus, 15,255 out of $64,057 \mathrm{Km} 2$ of the Khuzestan's total area was under the Iraqi occupation and the major settlements of the province either occupied or under seizure and other populated areas were close to the front. The downtowns of the historic Susa and Dezful were only three and twenty four Kilometer from the battle ground and Ahvaz the province capital of Khuzestan was just forty eight kilometer from the enemy line. Also, the strategic military facilities and the headquarters of Karkheh, Do-Kokeh, Dezful's Air Force (station for the F- 5 Tiger and F-4 Phantoms Jets) and Dezful's 2nd Armored Division Brigade of the 92-Ahvaz Army45 (station for the Chieftain tanks) all were located at west and north-west of Dezful and roughly two and twenty kilometer from the Iraqi front. In addition, Dezful strategic location alongside of the traditional route of KhoramShahr-Tehran at eastside of the Dez River; put the Iranian Army in difficult position and in shortage of military alternatives. Because, losing the city would disable the army to defend Ahvaz and the oil industry related facilities and could eventually lead to loss of the whole province [19]

By 15th October 1980, the Dezful's 2nd Armored Division Brigade launched the Operation Dezful to stop the Iraqi Army crossing the Karkheh River and progress in north of Khuzestan toward Dezful. The operation was designated to push back the Iraqis thirty two to fifty two kilometer behind the DoVaraj River next to Musian and save Dehloran also free the Dasht-e Abbas, Dasht-e Akbar, Cham-Hendi, Sendal and Kheyzar areas. The operation covered roughly some $3519 \mathrm{~km} 2$. During this battle the Iranian Army unleashed the Chieftain tanks against the Iraqi T62 and T-63 tanks. Soon, the Iraqi retreated back tactically and pull the Iranian tank column into an ambush within the Dasht-e Abbas. The Iranians lost twenty five Chieftain Tanks, but managed to hold the western coast of the Karkheh River and advance ten to twenty four kilometer in different positions toward DoVaraj River. The Operation of Dezful consider as the first counteroffensive during the Iran-Iraq War, which led to the major tanks Battle of Dezful in January next year. This battle proven the skill of the royal army, also the quality of the western technology compare to the Russian military hardware.

The Battle of Dezful: On 17th August 1980, this operation was designated by the Major General Valiollah Fallahi [20], the Commander of the Ground Forces to free the western portion of Khuzestan and push back the Iraqi forces behind the internationally recognized Iran-Iraq border. On 5th January 1981, the Battle of Dezful was launched in a distance between Ahvaz, Susangerd and Dezful. This $150.000 \mathrm{Km}$ long line of attach is consider as the major tank-battle after the Battle of Kursk during the World War II in 1943.

During this battle, the 1st and 3rd Armored Division Brigades of the 16-Qazvin Army under command of Colonel Syros Lotfi, Dezful's 2nd Armored Division Brigade and the 92-Ahvaz Army elements alongside the 291st-Armored Division Brigade of the 77-Khorasan Army initiated the attack at 10:00 am. At early stage of the attack, at the center of the battle line the elements of 16-Qazvin Army penetrate the gap between the Iraq's 5th-Army and Iraq's 9th-Army to interrupt the communication and reinforcement of those armies. Simultaneously, at the southern part of the battle line the motorized unites of the 92-Ahvaz Army at two key positions of Farsiat and Malihan-Abadiah crossed the Karun River and attacked position of the Iraq's 5th-Army at south of Ahvaz and then joint with the units of 16-Qazvin Army at Jofir area. At the same time, Dezful's 2nd Armored Division Brigade held its position at western shore of Karkheh River against any counterattack of the Iraq's 11thArmy north of the battle field.

During the first stage of this battle, the Iraqi forces tactically withdraw and put the Iranian forces into the ambush situation. On 6th January, the Iraqi forces reorganized and the 10th and 43rd-Armored Division Brigades of Iraq's 9th-Army facilitated by Russian made T72 tanks initiated counterattack. The two tank forces battled for four days. The Iranians withdrew, leaving many tanks stuck in the mud or out of fuel. On 7th January, the Iraqi forces managed to secure the Hoveyzeh-Susan gerd highway toward. However, the outcomes of the Battle of Dezful were grave enough for the Iranian military leaders to adjustment the untrained paramilitary as human-waveforce attacking strategy instead of engagement of the military hardware. Since, 27th September 1981 by the Operation Thamen Al-Aemeh until 16th March 1988 during the Operation Valfajr-10; fifteen large scale battles took place based on the human-wave attacks with disastrous outcomes for the Ahvaz, both sides [21].

However, as Martin J. Martinson claims [22]: the Iran-Iraq war is struggle without an end; the extreme bloody hostility was continued for continuing 
eight-year. The two oil wealth countries became a hot market for west and east. In addition, during the war Afghanistan, Pakistan, Syria and Turkey became four black markets for exporting legal and illegal weapons of the mass destruction such as nuclear, biological and chemical.

1982 March 29 Hussein proposes withdrawal to international borders. Iran ignores the offer and continues to advance. Following initial Iraqi attacks that seized some territory, the Iranians began gradually nibbling back until achieving some success in the center, in 1982.

1983 Fighting continues with Iran advancing. Soon, on the Dezful's Front, those two army divisions secured the territory bounded by the line KhoramShahr-Ahvaz-Susangerd-Musian in Khuzestan and Ilam Provinces. For the next seven-days the Iraqi forces continued to progress toward Karkheh and Dez Rivers, and the foothills of the Zagros Mountains to block the Abadan- Ahvaz-Tehran highway. Thus, the Iraqis successfully occupied the town Mehran and advanced towards the foothills of the Zagros Mountains and eventually block the traditional route of BaghdadTehran. On 23rd September, the Iranian air force initiated.Operation Kaman-99, a large-scale aerial bombardment against the Iraqi military bases and strategic infrastructures such Mosul Airbase, Baghdad, and the Kirkuk oil refinery. On 24th September, the Iranian Navy attacked Basra and destroyed the two oil terminals near the Iraqi port of al-Faw, which stopped Iraq's ability to export oil.

1984 Feb 29-First reports that Iraq has used chemical weapons. March 27-Iraq attacks tankers bound for Iranian ports. June 11-Iran and Iraq agree to ban on shelling civilian targets. 1985 March-Iran and Iraq fire missiles into each other's population centers, beginning the "war of cities." In 1985 Iraqi planes destroyed a partially constructed nuclear power plant in Bushehr, followed by bombing of civilian targets which in turn led to Iranian shelling of Basra and Baghdad.

1986 Aug 12-For the first time, Iraq bombs Iran's oil-loading facilities. 1987 Jan. 6-Hussein calls for cease-fire. Iran rejects it again. Jan. 9, 14-Iran seizes western bank of Shatt al Arab.

The war entered a new phase in 1987 when Iran increased hostilities against commercial shipping in and around the Gulf, resulting in naval escorts being sent to the area by the USA and other nations.

In May 1987 the US frigate Stark, calmly sailing the waters of the Persian Gulf, was suddenly blown apart by an Exocet missile fired from a jet fighter of Iraq's Saddam Hussein. A fifth of the ship's crew were killed and many others horribly burned or wounded. This event jumpstarted one of the most mysterious conflicts in American history: "The Tanker War," waged against Iran for control of the Persian Gulf [23].

This quasi-war took place at the climax of the mammoth Iran-Iraq War, during the last years of the Reagan administration. Losing on the battlefield, Ayatollah Khomeini's Iran had decided to close the Persian Gulf against shipping from Iraq's oil-rich backers, the emirate of Kuwait. The Kuwaitis appealed for help and America sent a fleet to the Gulf, raising the Stars and Stripes over Kuwait's commercial tankers.

The result was a free-for-all, as the Iranians laid mines throughout the narrow passage and launched attack boats against both tankers and US warships. The sixth largest ship in the world, the tanker Bridgeton, hit an Iranian mine and flooded. The US Navy fought its largest surface battle since World War II against the Ayatollah Khomeini's assault boats [24].

Meanwhile, US Navy Seals had arrived in the Gulf, setting up shop aboard a mobile platform from which they would sally out in fast craft to combat the Iranians. As Saddam Hussein, who had instigated the conflict, looked on, Iranian gunners fired shore-based Silkworm missiles against US ships, actions which, if made known at the time, would have required the US Congress to declare war against Iran.

But other cables sent warnings back to Washington that were frequently voiced by Iraqi officials they spoke to: that if the Americans left, then Iran would fill the vacuum. America accomplished its immediate goals in the first war: it halted Iran's advance into Iraq, defended the tankers in the Gulf, and contained the war from spreading into the Arabian Peninsula. Khomeini did not conquer Basra and Baghdad and march on Jerusalem as he dreamed he would.

It reshaped the way the United States looks at political alliances in the Middle East. Alex Chadwick talks with NPR diplomatic correspondent Mike Shuster [26] about America's military and diplomatic support of Saddam Hussein during that decade-long war, and the consequences of those ties today. But today, Iran is the dominant foreign power in Baghdad, thanks in large part to another war America fought in the Gulf. Iran Dominates in Iraq After U.S. 'Handed the Country Over'.

The Central Front saw only minor conventional battles until Iraq launched several major blows in 1988. In the north, fighting primarily revolved around several Kurdish insurgencies in northern Iraq, and culminated in the horror of the Halabcheh gas attack. The final campaign of the war saw Iraqsupported Iranian émigrés launching a spectacular, but also a swiftly-crushed, invasion of their homeland [25]. 
The eighth year of the Iran-Iraq War is nearly over, but the conflict shows little sign of ending anytime soon. Despite the dramatic events of April, when U.S. and Iranian naval forces clashed in the Persian Gulf, 1988 appears destined to be just another year of bloody stalemate in a seemingly endless war.

On 22 March 1988, the hitherto obscure Kurdish town of Halabcheh in the northeastern mountains of Iraq suddenly skyrocketed to prominence in the Western press as the site of the most recent and perhaps most grievous atrocity of the Iran-Iraq war. New York Times coverage on the same day was relegated to a page 11 story captioned "Protest at UN on Chemical Arms." According to the report, "Iran's chief delegate accused Iraq today of killing 5,000 people and wounding 5,000 more since Wednesday in attacks against 'pro-Iranian Kurdish villagers [27]." The article was almost completely overshadowed by the continuation of a front-page report on 54 Iranian seamen feared dead after an Iraqi attack on their ship in the Gulf.

In July 1988, nervous sailors aboard the cruiser USS Vincennes shot an Iranian airliner out of the sky, killing 300 civilians [28]. This event came one month before the end of the war, and may have been the final straw to influence the Ayatollah Khomeini to finally drink from his "poisoned chalice."

July 20 U.N Security Council unanimously votes for Resolution 598 calling for a cease-fire. 1988 July 18-Iran accepts year-old Security Council Resolution 598. Iraq had accepted it previously. Aug 20 Cease-fire takes hold. U.N troops deploy along border. Aug 25 indirect Iran-Iraq negotiations begin in Geneva. 1990 Aug 15 Hussein offers peace settlement to Iran.

The Iran - Iraq War, which ended in August 1988 , one month short of its eighth anniversary, was one of the longest, bloodiest and costliest. Third World armed conflicts in the twentieth century. Professor Karsh [29] addresses the causes of the Iran-Iraq War, unpacking the objectives of the two belligerents and examining how far objectives were matched by strategy. He assesses the war's military lessons regarding such key areas as strategy, tactics and escalation and in particular the use of non-conventional weapons, Finally, he examines the utility of armed force as an instrument of foreign policy.

Iran - Iraq war and ceasefire roughly cost two and half million lives and injuries, four million refugees and forced millions to mobilize along the war zone, while many cities were destroyed. Iranian government official figure of 213,255 casualties, estimates can range higher, economic loss around US\$ 500-1000 billion.
There were no "good guys" in the Iran-Iraq War, only two brutal dictatorships. Saddam Hussein was a megalomaniac who built enormous, ugly monuments to his ambitions and dreamed of becoming the dominant power in the Persian Gulf, controlling the world's oil supplies, and destroying Israel. At the end of the first Gulf War in 1988.

Iran-Iraq War, (1980-88), prolonged military conflict between Iran and Iraq during the 1980s. Open warfare began on September 22, 1980, when Iraqi armed forces invaded western Iran along the countries' joint border, though Iraq claimed that the war had begun earlier that month, on September 4, when Iran shelled a number of border posts. Fighting was ended by a 1988 cease-fire, though the resumption of normal diplomatic relations and the withdrawal of troops did not take place until the signing of a formal peace agreement on August 16, 1990.

\section{CONCLUSION}

The imposed Iraq-Iran war which began in 1980 and lasted until 1988 was one of the longest military conflicts in the 20th century and extended beyond $1,200 \mathrm{~km}$ of the western and southwestern Iranian borders.

For Iraqi planners, the only uncertainty was the fighting ability of the Iranian air force, equipped with some of the most sophisticated American-made aircraft. Despite the execution of key air force commanders and pilots, the Iranian air force had displayed its might during local riots and demonstrations. The air force was also active in the wake of the failed United States attempt to rescue American hostages in April 1980. This show of force had impressed Iraqi decision makers to such an extent that they decided to launch a massive preemptive air strike on Iranian air bases in an effort similar to the one that Israel employed during the June 1967 Arab-Israeli War.

The Iraqi offensive was initially successful, capturing the port city of Khorramshahr by the end of 1980. Iranian resistance proved strong, however, and Iraqi troops had withdrawn from the occupied portions of Iran by early 1982. Nevertheless, Iranian leader Ruhollah Khomeini declared that Iran would not cease fighting until Saddam's regime was toppled. Iran began a series of offensives, which proved successful enough to cause Iraq to resort to the use of chemical weapons, a tactic reviled by the international community. Iranian troops captured the oil-rich Majnoon Islands from Iraq in Feb, 1984, and southern Iraq's Fao peninsula in early 1986. Sporadic air and missile attacks on cities and military installations were common throughout the war, and in 1985 both sides began to strike their opponent's capital. The United States and several Western European nations became involved in the war in 1987, in response to Iranian attacks on Kuwaiti oil tankers traveling in the Persian Gulf. These attacks sullied 
Iran's international reputation considerably, making it difficult for Khomeini to obtain Arms. Finally, in July, 1988, Iran was forced to accept a United Nationsmandated cease-fire. Estimates of the number of dead range up to 1.5 million. In its war effort, Iran was supported by Syria and Libya, and received much of its weaponry from North Korea and China, as well as from covert Arms transactions from the United States. Iraq enjoyed much wider support, both among. Arab and Western nations: the Soviet Union was its largest supplier of Arms. In 1990 Iraq, concerned with securing its forcible annexation of Kuwait, agreed to accept the terms of the 1975 treaty with Iran and withdraw its troops from Iranian territory as well as exchange all prisoners of war. An agreement was not signed, however, and both sides held thousands of POWs for many years. Several prisoner exchanges and releases occurred after 1988; the final exchange took place in 2003.

Although the war ended in 1988, it led to numerous aftershocks that rippled throughout the region including the Iraqi invasion of Kuwait in 1990, the liberation of Kuwait a year later, and the U.S. invasion of Iraq in 2003. The seeds of multigenerational tragedy were planted the Iran -Iraq War. The world will live with its consequences for decades, if not longer.

\section{REFERENCES}

1. Venter AJ. Iran's Nuclear Option (Tehran's Quest for the Atom Bomb), Casemate, UK, 2005; 45.

2. Marr P. The Modern History of Iraq, New York. Avalon Publishing, 2012; 132.

3. Cowley R, Parker G. The Reader's Companion to Military History, New York, 2001; 228.

4. Hooglund EJ. The Iranian Revolution: Review Article. Middle East Journal, 1980; 34(4): 485489.

5. Barreet R. Intervention in Iraq (1958-1960), The Middle East Institute, 2008 April; 48.

6. Vermilya D. The Iran-Iraq War: Causes \& Timeline, Uploaded by The Study.com Video Team. 2014 Oct 26.

7. Razoux P. The Iran-Iraq War, Harvard University Press, 2015 November 3; 70.

8. Ayatollahi-Tabaar M. Causes of the US Hostage Crisis in Iran: The Untold Account of the Communist Threat, Journal Security Studies, 2017 Jul 7; 26(4):665-697.

9. Tucker SC. The Encyclopedia of Middle East Wars (The United States in Persian Gulf, Afghanistan, and Iraq conflicts), Oxford University, 2010; 586-7.

10. El Azhary MS. The Iran -Iraq War (An Historical, Economic and Political Analysis), London and New York, 2011; 2.
11. Abdulghani JM. Iraq and Iran (The Years of Crisis), London, 2011; 204.

12. Hilaire M. Waging Peace (The United Nations Security Council and Transnational Armed Conflicts) Berlin, 2015; 518-522.

13. Cummins J. The War Chronicles (From Flintlocks to Machine Guns), USA, 2009; 395.

14. Rachman G. Iran - Iraq War, Financial Times, 2017; https://www.ft.com/content/ffdd9c08-916711e7-bdfa-eda243196c2c

15. The UN Refugee Agency. International Protection Consideration with Regard to People Fleeing the Republic of Iraq, UN, 2019; 79-83.

16. Woods KM, Murray W, Holaday TH, Elkhamri M. Saddam War (An Iraqi Military Perspective of the Iran - Iraq War) Washington D.C, 2009; 70.

17. Ali M, Horizon P. The Impact of the Iran-Iraq War, Pakistan Institute of International Affairs, 2014; 33(4): 21-34

18. Toronto NW. How Militaries Learn Human Capital, Military Education, and Battlefield Effectiveness, London, 1992; 133.

19. Karbasian M. Iranian Oil Industry Turns 100, International Iran Magazine, No, 48849. September 2008.

20. Moazami-Goodarzi J. The Formative Years of the Syrian-I Ran Ian Alliance: (Power Politics In The Middle East 1979-1989), London University, 2014; 61-2.

21. Hiro D. The Longest War: The Iran-Iraq Military Conflict, Routledge, 1990 December 21.

22. Martin J. The Iran-Iraq War: Struggle without end (Student research and writing AY: 1983-84) Oxford University, 1984 January 1; 135-50.

23. Zatarain LA. Tanker War (America's First Conflict with Iran, 1987-88), Casemate - UK, 2009 January; 16.

24. Mansoor PR, Murray W. The Culture of Military Organization, Cambridge University, 2019; 355.

25. Cooper P. The Iran-Iraq War, Middle East@War, 2018 April 5; 9.

26. Chadwick A, Shuster M. U.S. Links to Saddam During Iran-Iraq War, npr.org 2005 September 22; https://www.npr.org/templates/story/story.php?stor yId $=4859238$

27. Pour S, Beaudin V. THE REAL VICTIMS OF THE IRAN-IRAQ WAR, New York Time, 1988 Jun 5.

28. Zatarain LA. America's First Clash with Iran: The Tanker War, 1987 88, Casemate - UK, 2010 November 22; 175.

29. Karsh E. The Iran-Iraq War 1980-1988, USA, 2002; 42-5. 